\title{
SISTEM INFORMASI JADWAL PERKULIAHAN MENGGUNAKAN MEDIA TELEVISI (STUDI KASUS PADA JURUSAN TEKNIK INFORMATIKA UPN “VETERAN" YOGYAKARTA)
}

\author{
Sundari Retno Andani, Subastian Wibowo, Poningsih \\ Program Studi Manajemen Informatika, AMIK Tunas Bangsa Pematangsiantar \\ Jln. Jenderal Sudirman Blok A No. 1,2,3 Pematangsiantar \\ Magister STMIK AMIKOM Yogyakarta \\ Jln. Ring Road Utara, Condong Catur, Sleman, Yogyakarta \\ Sundari.ra@amiktunasbangsa.ac.id, subastian.w@students.amikom.ac.id, \\ poningsih@amiktunasbangsa.ac.id
}

\begin{abstract}
Students are always confused with a schedule of lectures, about time of lectures, room that will be used, even about come or not the lecturer on class. As a result, students must always go to the education department to inquire this issue. It is very ineffective. But there is no system that helps students in overcoming this problem. In this paper, the authors build a system with the title is the information system of the schedules of lectures using television. The system is built using Delphi 6.0 programming language and uses Microsoft Access 2003 as the database. To operate this system requires a CPU and a television screen as an output device. This system provides information on the schedule of lectures to the students through a television screen. Information provided includes schedule of lectures, room that will be used, the certainty of the lecture will take place, and informing announcements and activities that will take place. These systems also support the effectiveness of the performance of educational staff in the conduct of daily operations.
\end{abstract}

Keywords: information system, schedule of lectures

\begin{abstract}
Abstrak
Mahasiswa selalu dibingungkan dengan jadwal perkuliahan, baik mengenai waktu perkuliahan, ruangan yang akan digunakan, bahkan mengenai datang atau tidaknya dosen yang mengajar. Akibatnya mahasiswa harus selalu ke bagian pendidikan untuk menanyakan masalah ini. Hal ini sangat tidak efektif. Namun belum ada sistem yang membantu mahasiswa dalam mengatasi masalah ini. Pada jurnal ini, penulis membangun sebuah sistem dengan judul sistem informasi jadwal perkuliahan menggunakan media televisi. Sistem ini dibuat dengan menggunakan bahasa pemrograman Delphi 6.0 dan menggunakan Microsoft Access 2003 sebagai databasenya. Untuk


mengoperasikan sistem ini diperlukan sebuah CPU dan sebuah layar televisi sebagai output device. Sistem ini memberikan informasi mengenai jadwal perkuliahan kepada mahasiswa melalui sebuah layar televisi. Informasi yang diberikan mencakup jadwal perkuliahan, ruangan yang akan digunakan, kepastian pelaksanaan perkuliahan, ruangan yang akan digunakan, kepastian pelaksanaan perkuliahan yang akan berlangsung, serta menginformasikan pengumuman-pengumuman dan kegiatan-kegiatan yang akan berlangsung. Sistem ini juga menunjang efektifitas kinerja staff pendidikan dalam melakukan kegiatan operasional sehari-hari.

Kata kunci: sistem informasi, jadwal perkuliahan

\section{PENDAHULUAN}

Revolusi pada dunia ilmu pengetahuan dan teknologi telah memicu lahirnya pola baru dalam penyampaian maupun penerimaan informasi, dimana pola penyampaian informasi yang lazim dilakukan sekarang ini adalah memanfaatkan komputer, monitor dan televisi sebagai piranti medianya.

Pada saat ini, mahasiswa selalu dibingungkan oleh masalah pelaksanaan perkuliahan. Baik mengenai waktu pelaksanaan perkuliahan, ruangan yang akan digunakan, bahkan mengenai kepastian pelaksanaan perkuliahan yang akan berlangsung. Akibatnya mahasiswa harus selalu ke bagian ke pengajaran hanya untuk menanyakan masalah ini. Hal ini sangat tidak efektif.

Berdasarkan masalah di atas dan pentingnya pengaturan jadwal dengan baik, maka penulis membangun sistem informasi jadwal perkuliahan menggunakan media televisi. Sistem ini akan memberikan informasi mengenai pelaksanaan perkuliahan kepada mahasiswa melalui sebuah layar televisi. Informasi yang diberikan mencakup waktu pelaksanaan perkuliahan yang akan berlangsung, bahkan menginformasikan pengumumanpengumuman dan kegiatan-kegiatan yang akan berlangsung.

Sebelumnya, penyampaian jadwal dan informasi kepada mahasiswa masih menggunakan media kertas dan papan pengumuman. Hal ini jika dilihat dari sudut pandang waktu merupakan hal yang tidak efisien. Penyampaian informasi yang cepat, efisien dan akurat juga dapat meningkatkan dan mendapatkan pengakuan dari masyarakat. Saat ini persaingan antar perguruan tinggi begitu ketat dalam menghasilkan sumber daya manusia yang unggul dan berkualitas, baik teori maupun praktek, serta dituntut memiliki kemampuan analisis dan logika berpikir dengan cermat dan tajam. 


\section{METODE PENELITIAN}

\subsection{Sistem Informasi}

[4]Sistem Informasi adalah kombinasi dari teknologi informasi dan aktivitas orang yang menggunakan teknologi itu untuk mendukung operasi dan manajemen. Dalam arti yang sangat luas, istilah sistem informasi yang sering digunakan merujuk kepada interaksi antara orang, proses algoritmik, data, dan teknologi. Dalam pengertian ini, istilah ini digunakan untuk merujuk tidak hanya pada penggunaan organisasi teknologi informasi dan komunikasi (TIK), tetapi juga untuk cara di mana orang berinteraksi dengan teknologi ini dalam mendukung proses bisnis.

Sistem informasi terdiri dari komponen-kompenen yang disssebut dengannn issstilah blok bangunan (building block), yaitu blok input (input block), blok model (model block), blok keluaran (output block), blok teknologi (technology block), blok basis data (database block) dan blok kendali (control block).

\subsection{Metode Waterfall}

[1]Model proses yang digunakan untuk pengembangan sistem perangkat lunak yang telah lama dikenal secara luas adalah model atau paradigma siklus hidup klasis yang disebut waterfall. Model ini sangat terstruktur dan bersifat linier. Model ini memerlukan pendekatan yang sistematis dan sekuensial di dalam pengembangan sistem, analisis, perancangan, implementasi, pengoperasian dan pemeliharaan.

\subsection{Microsoft Access}

[2] Microsoft access adalah program manajemen data hebat yang bisa digunakan untuk menyortir, mengatur dan melaporkan informasi penting yang dibutuhkan user sehari-hari. Microsoft Access adalah program manajemen data hebat yang bisa digunakan untuk menyortir, mengatur dan melaporkan informasi penting yang dibutuhkan user sehari-hari. Microsoft access membantu user mengelola database dengan cara menyediakan struktur yang efisien untuk menyimpan dan mengambil informasi. Karena Microsot Access adalah sistem manajemen database relasional (RDBMS), user dapat mengatur data tentang subyek-subyek yang berbeda ke dalam tabeltabel, kemudian membuat hubungan di antara tabel untuk menghindari adanya penggandaan data, menghemat ruang simpan dalam komputer dan memaksimalkan kecepatan dan akurasi bekerja dengan data.

\subsection{Bahasa Pemrograman Delphi}

[6]Borland Delphi adalah bahasa pemrograman berbasis Object Pascal yang bekerja dalam lingkup $M S$-Windows. Bahasa ini mempunyai kemampuan yang optimal, yaitu dapat dipakai untuk merancang program aplikasi yang berpenampilan seperti program aplikasi lainnya yang berbasis MS-Windows. Dalam bahasa pemrograman Delphi, terdapat bebera[pa istilah yang akan dijelaskan, yaitu form, unit, project, program, property dan event. 
Metode yang digunakan dalam perancangan dan pembuatan sistem ini adalah metode waterfall.

\subsection{Rancangan Proses}

Rancangan proses pada penelitian ini menggunakan bentuk data flow diagram (DFD). Hal pertama dalam perancangan DFD diperlukan pembuatan DFD Level 0 yang menggambarkan sistem secara keseluruhan.

a. DFD Level 0

Pada DFD level 0 digambarkan bahwa pemakai sistem adalah admin. Admin melakukan proses pada sistem informasi penjadwalan, kemudian user mendapatkan output terakhir berupa informasi. Aliran data yang terjadi pada DFD level 0 adalah sebagai berikut :

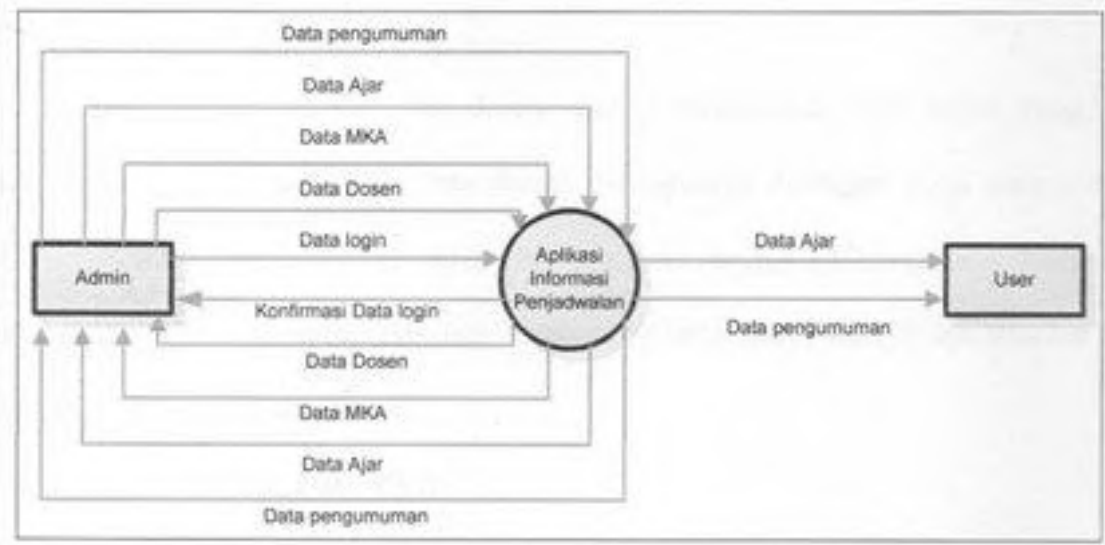

\section{Gambar 1. DFD Level 0}

b. DFD Level 1

Pada DFD level 1 terdiri dari 5 proses, yaitu proses login, proses mengolah data dosen, proses mengolah data MKA, proses mengolah data ajar, dan proses mengolah data pengumuman. Aliran data yang terjadi pada DFD level 1 adalah sebagai berikut : 
Jurnal Sains Komputer \& Informatika (J-SAKTI)

Volume (1) No. 1 Maret 2017

ISSN:2548-9771/EISSN: 2549-7200

http://ejurnal.tunasbangsa.ac.id/index.php/jsakti

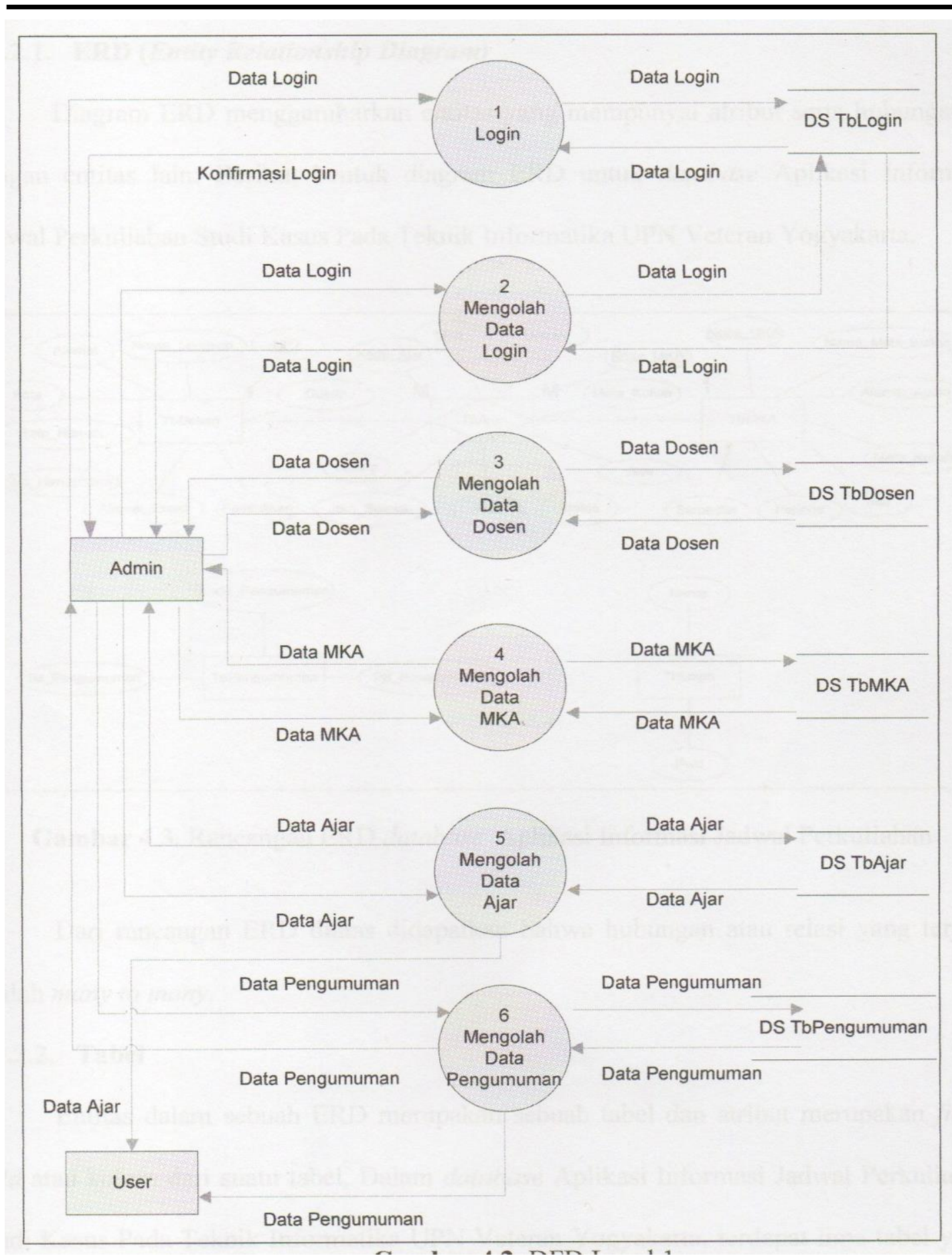

\section{Gambar 2. DFD Level 1}

\subsection{Rancangan Basis Data}

Rancangan basis data dimaksudkan untuk mengetahui adanya entitas dan atribut yang ada pada database serta hubungan/relasi antar entitas tersebut. Rancangan basis data ini menggunakan ERD (entity relationship diagram). 


\subsubsection{ERD (entity relationship diagram)}

Diagram ERD menggambarkan entitas yang mempunyai atribut serta hubungannya dengan entitas lain. Berikut bentuk diagram ERD untuk database Sistem Informasi Jadwal Perkuliahan.

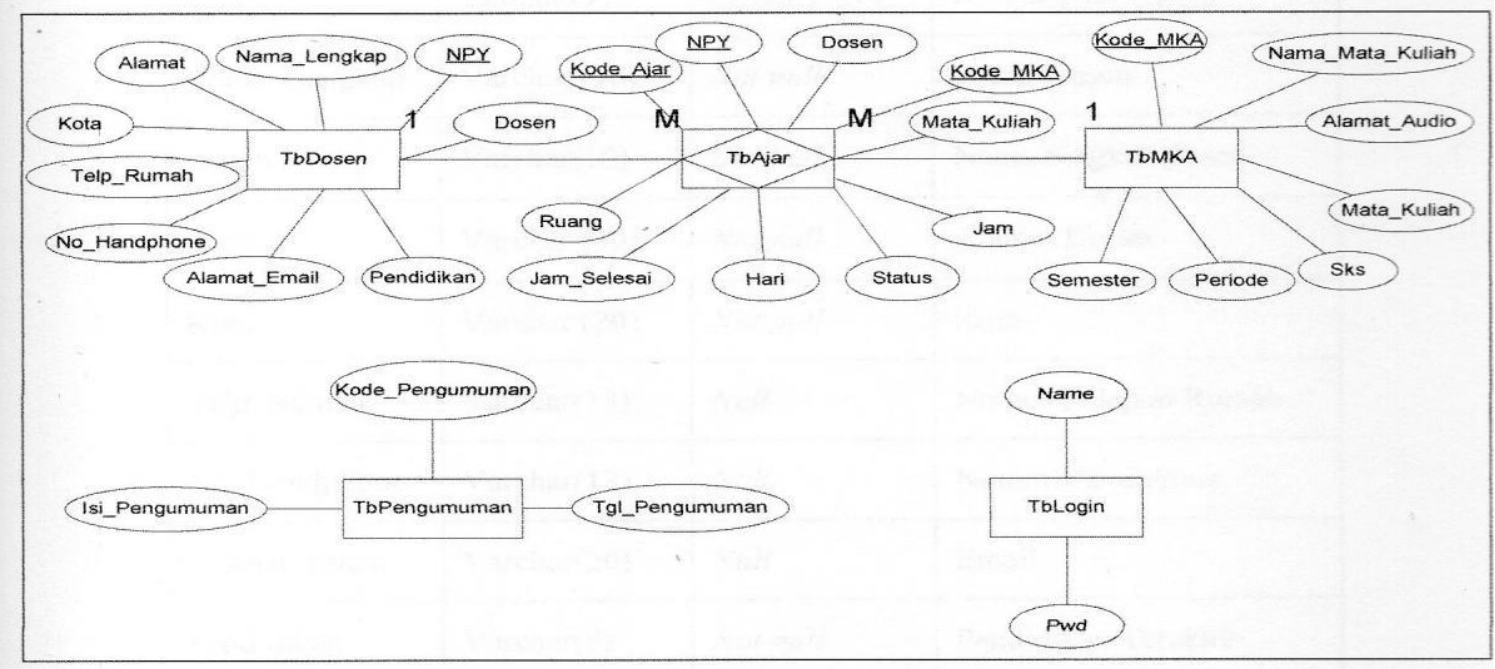

Gambar 3. Rancangan ERD Sistem Informasi Jadwal Perkuliahan

\subsubsection{Tabel}

Dalam database Sistem Informasi Jadwal Perkuliahan terdapat lima tabel, yaitu tabel TbDosen, tabel TbMKA, tabel TbAjar, tabel TBPengumuman dan tabel TbLogin. Berikut ini merupakan rancangan tabel yang digunakan :

a. Tabel TbMKA

Tabel TbMKA merupakan tabel yang akan menyimpan data matakuliah. Tabel ini berisi 7 field yaitu Kode_MKA, Nama_Mata_Kuliah, Mata_Kuliah, SKS, Semester, Periode. Dan Alamat_Audio, dengan Kode_MKA sebagai primary key.

\section{Tabel 1. Tb_MKA}

\begin{tabular}{|l|l|l|l|}
\hline Semester & varchar(1) & Not null & Semester \\
\hline Periode & Varchar(6) & Not null & Ganjil atau Genap \\
\hline Alamat_Audio & Varchar(255) & Not null & Alamat penyimpanan file \\
\hline
\end{tabular}


Jurnal Sains Komputer \& Informatika (J-SAKTI)

Volume (1) No. 1 Maret 2017

ISSN:2548-9771/EISSN: 2549-7200

http://ejurnal.tunasbangsa.ac.id/index.php/jsakti

\section{Tabel 2. Lanjutan Tb_MKA}

\begin{tabular}{|l|l|l|l|}
\hline Semester & varchar(1) & Not null & Semester \\
\hline Periode & Varchar(6) & Not null & Ganjil atau Genap \\
\hline Alamat_Audio & Varchar(255) & Not null & Alamat penyimpanan file \\
\hline
\end{tabular}

b. Tabel TbDosen

Tabel TbDosen merupakan tabel yang akan menyimpan data-data para dosen. Tabel ini berisi 9 field yaitu NPY, Nama_Lengkap, Dosen, Alamat, Kota, Telp_Rumah, No_Handphone, Alamat_Email dan Pendidikan, dengan NPY sebagai primary key.

Tabel 3. TbDosen

\begin{tabular}{|l|l|l|l|}
\hline \multicolumn{1}{|c|}{ Nama Data } & \multicolumn{1}{|c|}{ Tipe Data } & \multicolumn{1}{|c|}{ Constraint } & \multicolumn{1}{|c|}{ Keterangan } \\
\hline NPY & Varchar(9) & Primary Key & No Pegawai Dosen \\
\hline Nama_Lengkap & Varchar (40) & Not null & Nama Dosen \\
\hline Dosen & Varchar(10) & Not bull & Nama Singkat Dosen \\
\hline Alamat & Varchar(40) & Not null & Alamat Dosen \\
\hline Kota & Varchar(20) & Not null & Kota \\
\hline Telp_Rumah & Varchar(13) & Null & Nomor Telepon Rumah \\
\hline No_Handphone & Varchar(13) & Null & Nomor Handphone \\
\hline Alamat_Email & Varchar(20) & Null & Email \\
\hline Pendidikan & Varchar(5) & Not null & Pendidikan Terakhir \\
\hline
\end{tabular}

c. Tabel TbAjar

Tabel TbDosen merupakan tabel yang akan menyimpan data-data semua mata kuliah, baik dosen pengajar maupun waktu mata kuliah berlangsung. Tabel ini berisi 10 field yaitu Kode_Ajar, NPY, Kode_MKA, Hari, Jam, Jam_Selesai, Ruang dan status, dengan Kode_Ajar sebagai primary key. 
Jurnal Sains Komputer \& Informatika (J-SAKTI)

Volume (1) No. 1 Maret 2017

ISSN:2548-9771/EISSN: 2549-7200

http://ejurnal.tunasbangsa.ac.id/index.php/jsakti

Tabel.4. TbAjar

\begin{tabular}{|l|l|l|l|}
\hline \multicolumn{1}{|c|}{ Nama Data } & \multicolumn{1}{|c|}{ Tipe Data } & \multicolumn{1}{|c|}{ Constraint } & \multicolumn{1}{c|}{ Keterangan } \\
\hline Kode_Ajar & varchar(6) & Primary Key & Kode Ajar \\
\hline NPY & varchar(9) & Foreign Key & No Pegawai Dosen \\
\hline Kode_MKA & varchar(6) & Foreign Key & Kode Mata Kuliah \\
\hline Hari & varchar(6) & Not mull & Hari Ini \\
\hline Jam & Varchar(5) & Not null & Waktu mulai Perkuliahan \\
\hline Jam_Selesai & Varchar(5) & Not null & Waktu selesai perkuliahan \\
\hline Ruang & Varchar(10) & Not null & Ruang Perkuliahan \\
\hline Kondisi & Varchar(11) & Not null & Status Perkuliahan \\
\hline
\end{tabular}

d. Tabel TbPengumuman

Tabel TbPengumuman merupakan tabel yang akan menyimpan datadata semua pengumuman. Tabel ini berisi 3 field yaitu Kode_Pengumuman, Tgl_Pengumuman dan Isi_Pengumuman, dengan Kode_Pengumuman sebagai primary key.

Tabel 5. TbPengumuman

\begin{tabular}{|l|l|l|l|}
\hline \multicolumn{1}{|c|}{ Nama Data } & \multicolumn{1}{|c|}{ Tipe Data } & \multicolumn{1}{|c|}{ Constraint } & \multicolumn{1}{c|}{ Keterangan } \\
\hline Kode_Pengumuman & varchar(6) & Primary Key & Kode Pengumuman \\
\hline Tg1_Pengumuman & Varchar(10) & Not null & Tanggal Pengumuman \\
\hline Isi_Pengumuman & Varchar(255) & Not null & Isi Pengumuman \\
\hline
\end{tabular}

e. Tabel TbLogin

Tabel TbLogin merupakan tabel yang akan menyimpan data-data login. Tabel ini berisi 2 field yaitu Name dan Pwd, dengan Name sebagai primary key. 
Jurnal Sains Komputer \& Informatika (J-SAKTI)

Volume (1) No. 1 Maret 2017

ISSN:2548-9771/EISSN: 2549-7200

http://ejurnal.tunasbangsa.ac.id/index.php/jsakti

Tabel 6. TbLogin

\begin{tabular}{|c|c|c|c|}
\hline Nama Data & Tipe Data & Constraint & Keterangan \\
\hline Name & Varchar (15) & Primary Key & Username \\
\hline Pwd & Varchar (6) & Not null & Password \\
\hline
\end{tabular}

\subsubsection{RAT (Relasi Antar Table)}

RAT (relasi Antar Tabel) yang berguna sebagai gambaran hubungan antar tabel dimana tabel yang mempunyai relasi dapat saling berkomunikasi, seperti dapat dilihat pada gambar 4 .

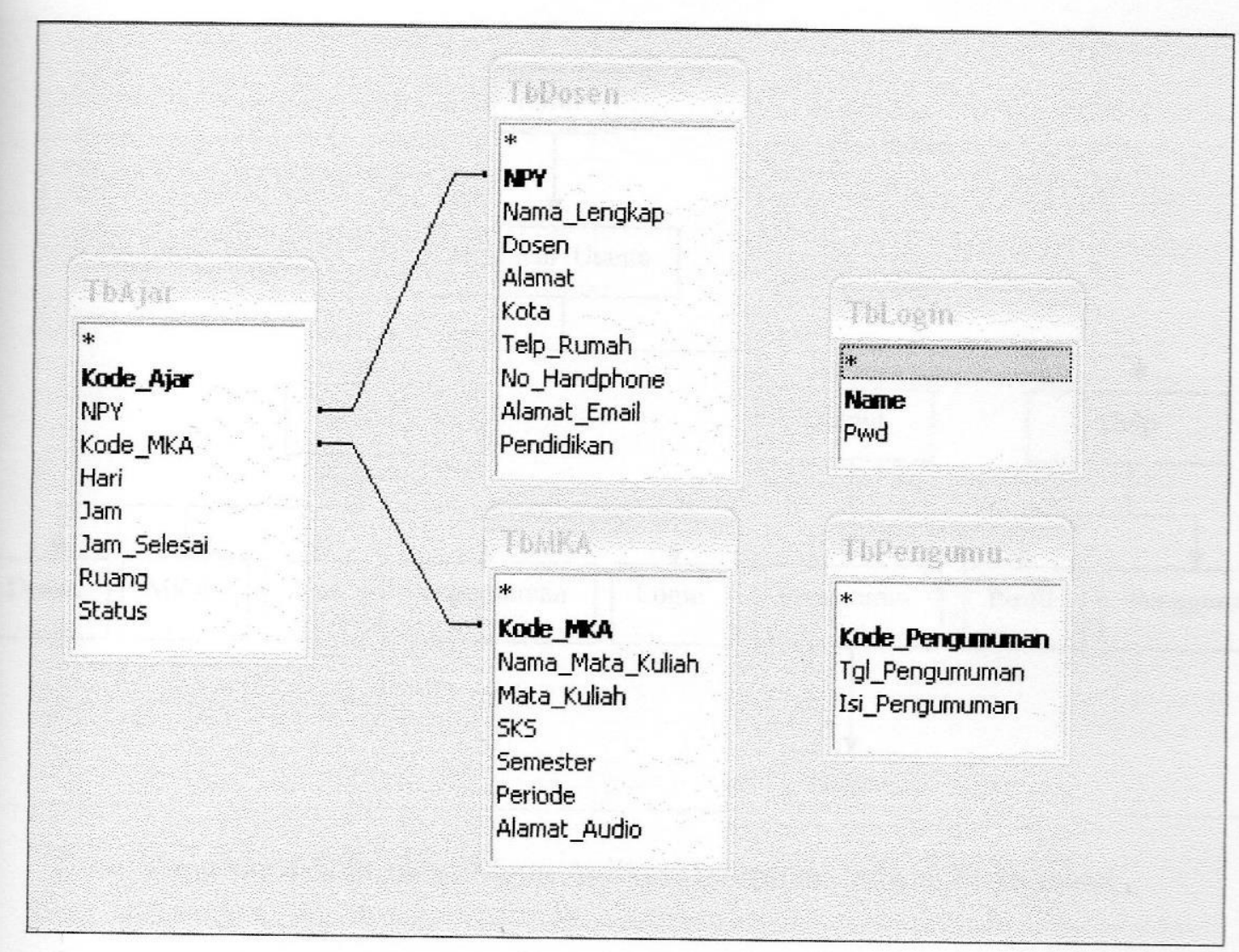

Gambar 4. Rancangan RAT database

\section{HASIL DAN PEMBAHASAN}

Sistem Informasi jadwal Perkuliahan Menggunakan Media Televisi dibuat dengan menggunakan bahasa pemrograman Delphi 6.0. 


\subsection{Implementasi Halaman Login}

Halaman Login digunakan untuk pemeriksaan username dan password yang dilakukan oleh admin untuk menuju ke halaman utama dari sistem. Adapun halaman Login dapat dilihat pada gambar 5.

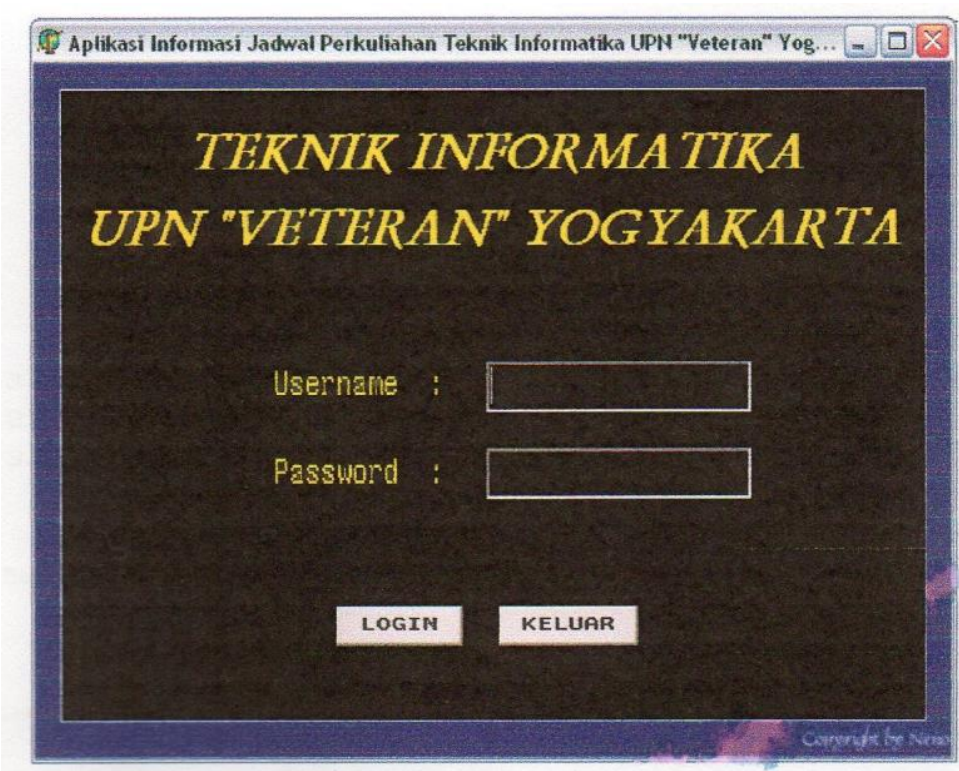

Gambar 5. Halaman Login

\subsection{Implementasi Halaman Utama}

Halaman Utama digunakan untuk memilih form yang akan dilihat. Diantaranya yaitu, FormDosen, FormMKA, FormAjar, FormPengumuman, FormLogin, FormJadwal, FormPenggunaan dan FormProfile. Adapun halaman Utama dapat dilihat pada gambar 6 .

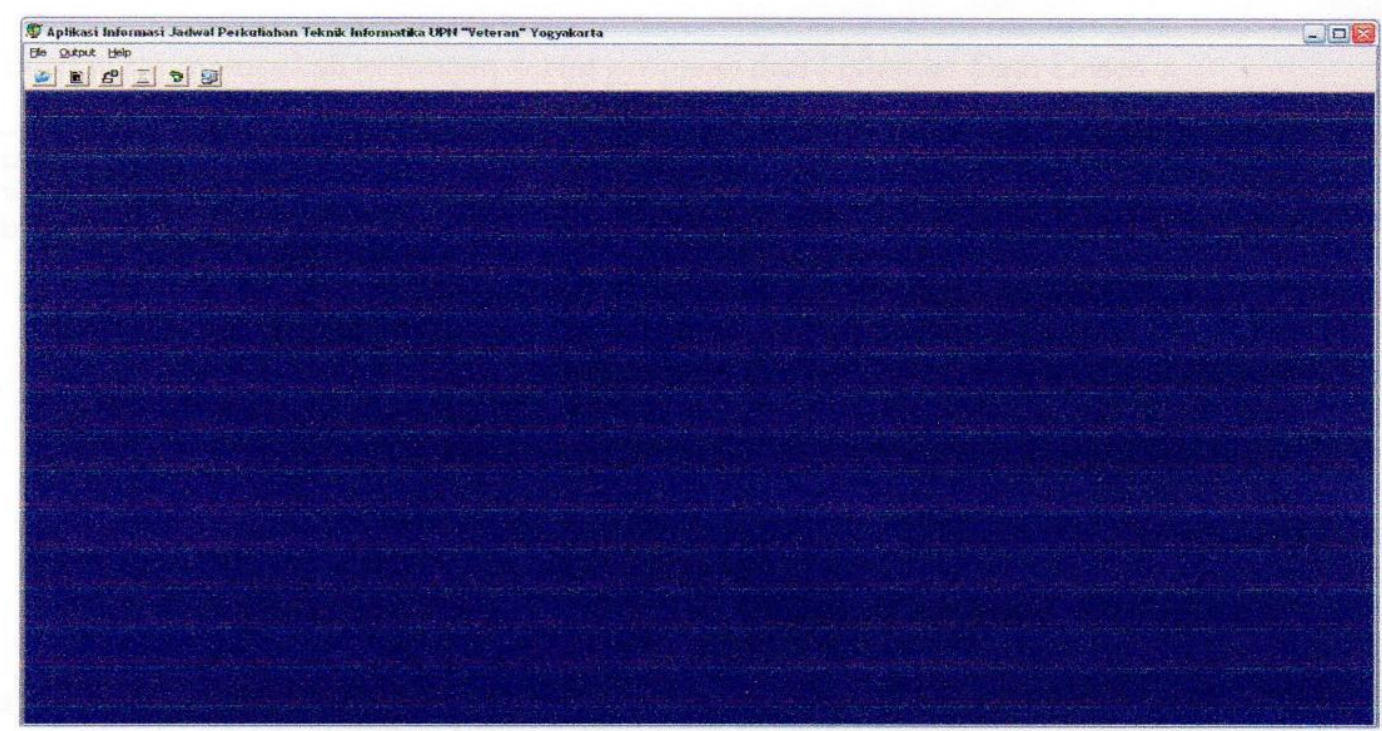

Gambar 6. Halaman Utama

Jadwal Perkuliahan Menggunakan Media Televisi (Sundari R.A)|128 
Jurnal Sains Komputer \& Informatika (J-SAKTI)

Volume (1) No. 1 Maret 2017

ISSN:2548-9771/EISSN: 2549-7200

http://ejurnal.tunasbangsa.ac.id/index.php/jsakti

\subsection{Implementasi Halaman Data Dosen}

Halaman Data Dosen digunakan mengolah data dosen. Adapun halaman data dosen dapat dilihat pada gambar 7 .

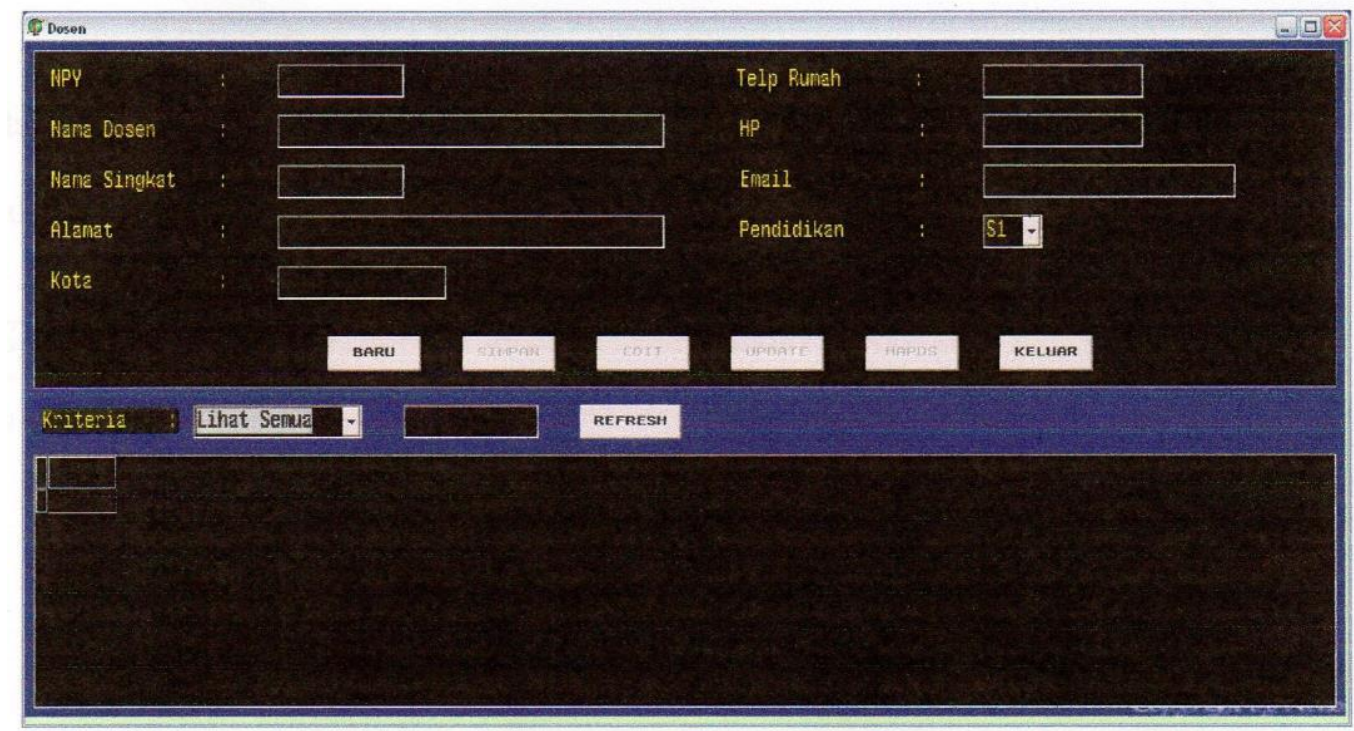

\section{Gambar 7. Halaman Data Dosen}

\subsection{Implementasi Halaman Data Mata Kuliah}

Halaman Data Mata Kuliah digunakan mengolah data mata kuliah. Adapun halaman data mata kuliah dapat dilihat pada gambar 8.

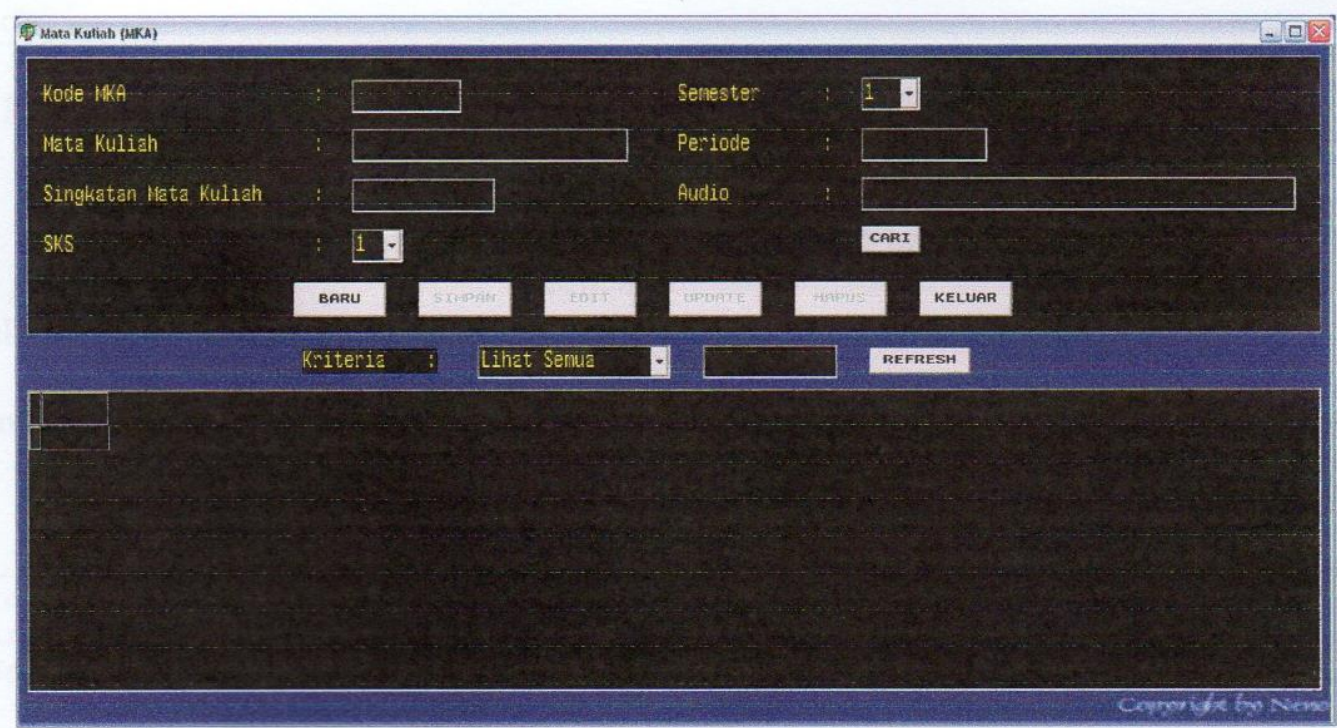

\section{Gambar 8. Halaman Data Mata Kuliah}

Jadwal Perkuliahan Menggunakan Media Televisi (Sundari R.A)|129 
Jurnal Sains Komputer \& Informatika (J-SAKTI)

Volume (1) No. 1 Maret 2017

ISSN:2548-9771/EISSN: 2549-7200

http://ejurnal.tunasbangsa.ac.id/index.php/jsakti

\subsection{Implementasi Halaman Data Ajar}

Halaman Data Ajar digunakan mengolah data ajar. Adapun halaman data ajar dapat dilihat pada gambar 9 .

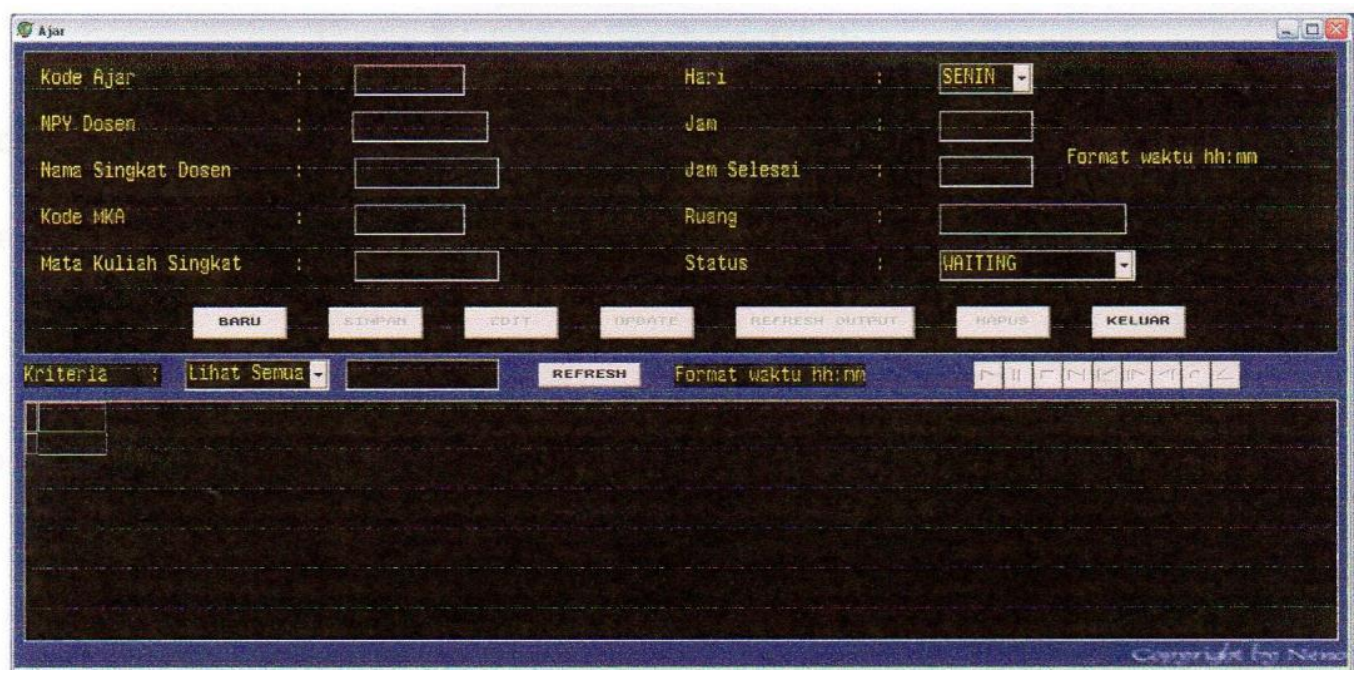

\section{Gambar 9. Halaman Data Ajar}

\subsection{Implementasi Halaman Data Pengumuman}

Halaman Data Pengumuman digunakan mengolah data pengumuman. Adapun halaman data pengumuman dapat dilihat pada gambar 10 .

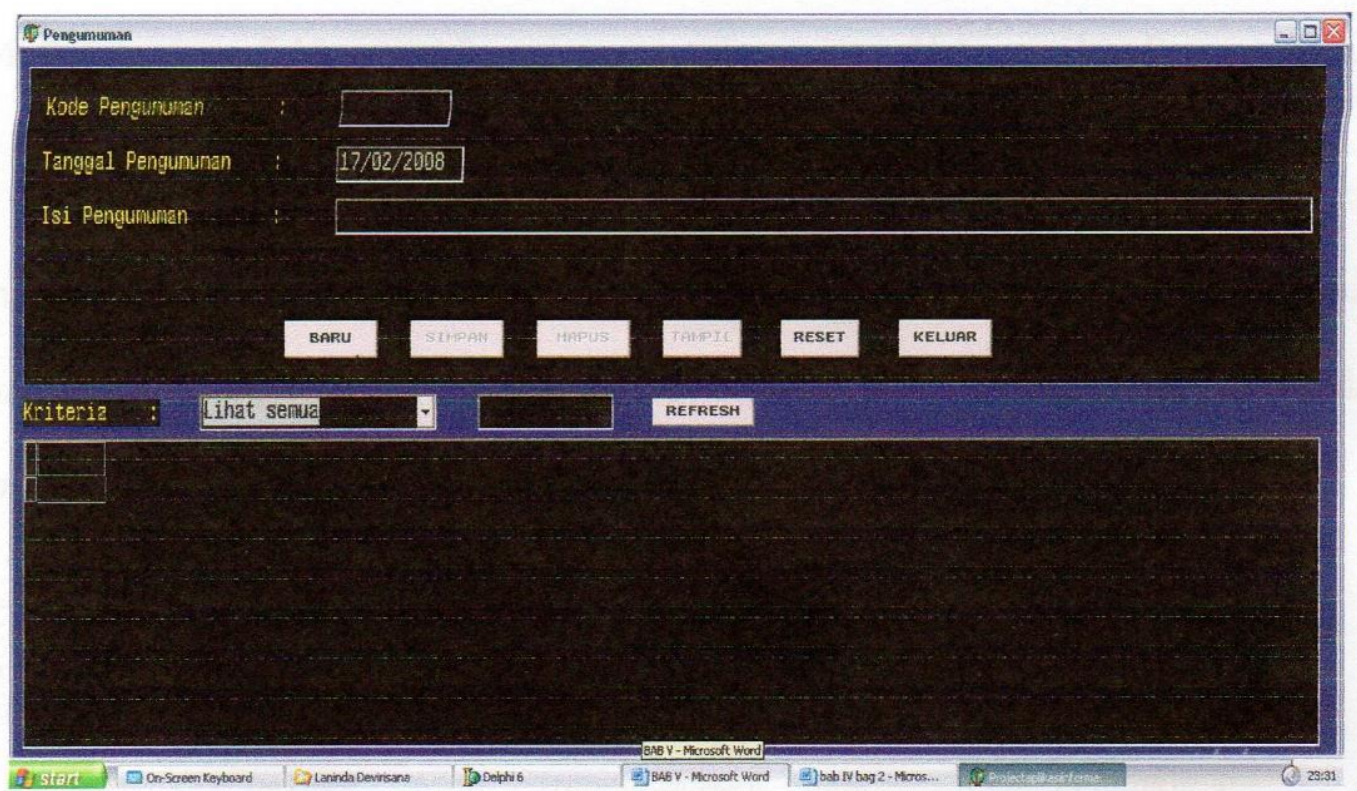

Gambar 10. Halaman Data Pengumuman

Jadwal Perkuliahan Menggunakan Media Televisi (Sundari R.A)|130 
http://ejurnal.tunasbangsa.ac.id/index.php/jsakti

\subsection{Implementasi Halaman Data Login}

Halaman Data Login digunakan mengolah data login. Adapun halaman data login dapat dilihat pada gambar 11.

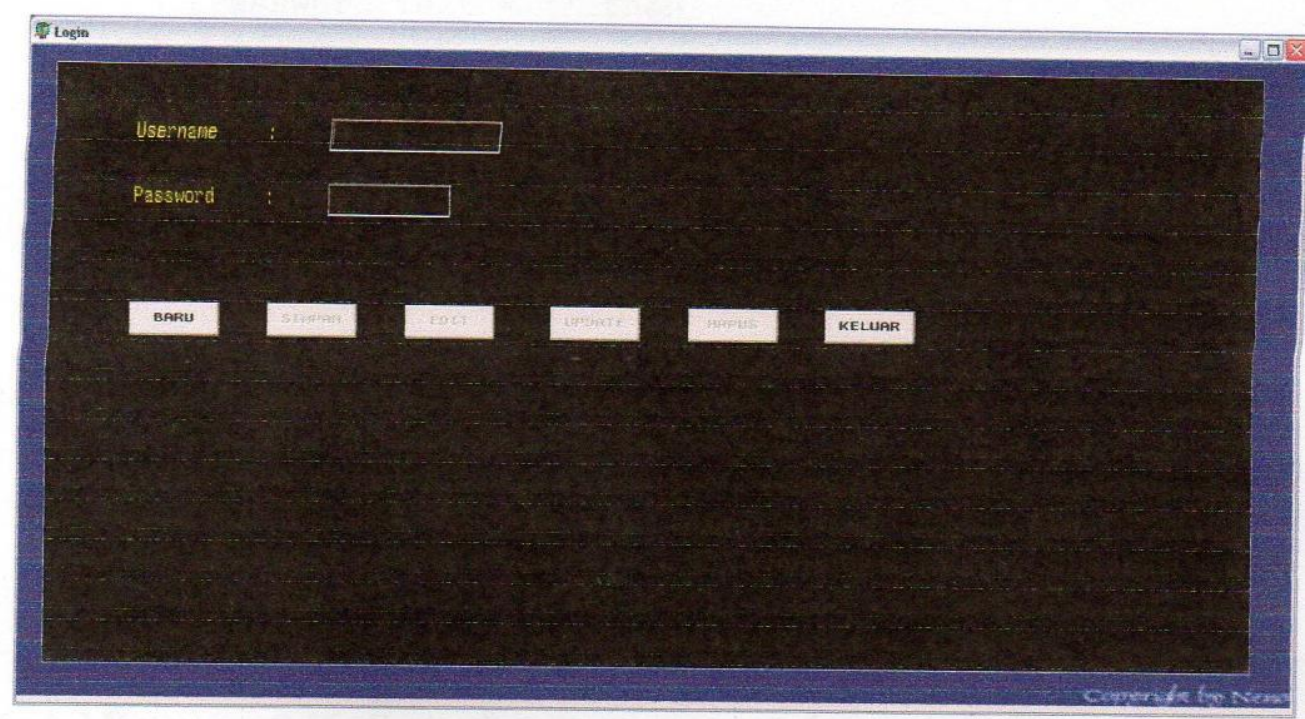

\section{Gambar 11. Halaman Data Login}

\subsection{Implementasi Halaman Pengaturan}

Halaman Pengaturan digunakan mengatur ata ajar dan data mka yang akan ditampilkan pada halaman jadwal. Adapun halaman pengaturan dapat dilihat pada gambar 12 .

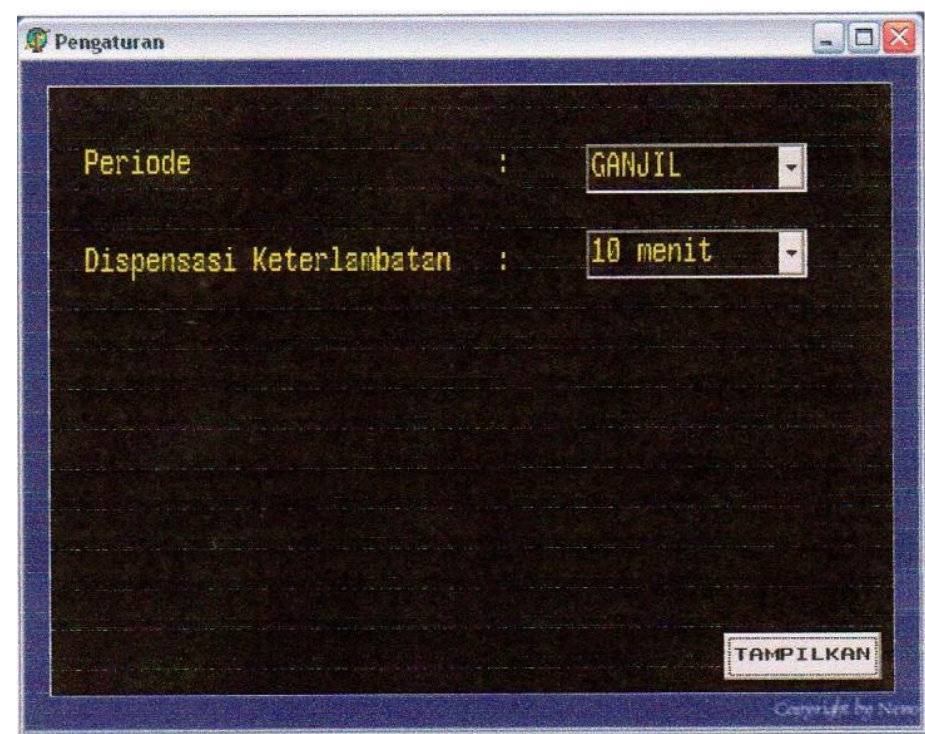

Gambar 12. Halaman Pengaturan 


\subsection{Implementasi Halaman Jadwal}

Halaman Jadwal digunakan untuk menyampaikan dan menampilkan jadwal kuliah.. Adapun halaman jadwal dapat dilihat pada gambar 13

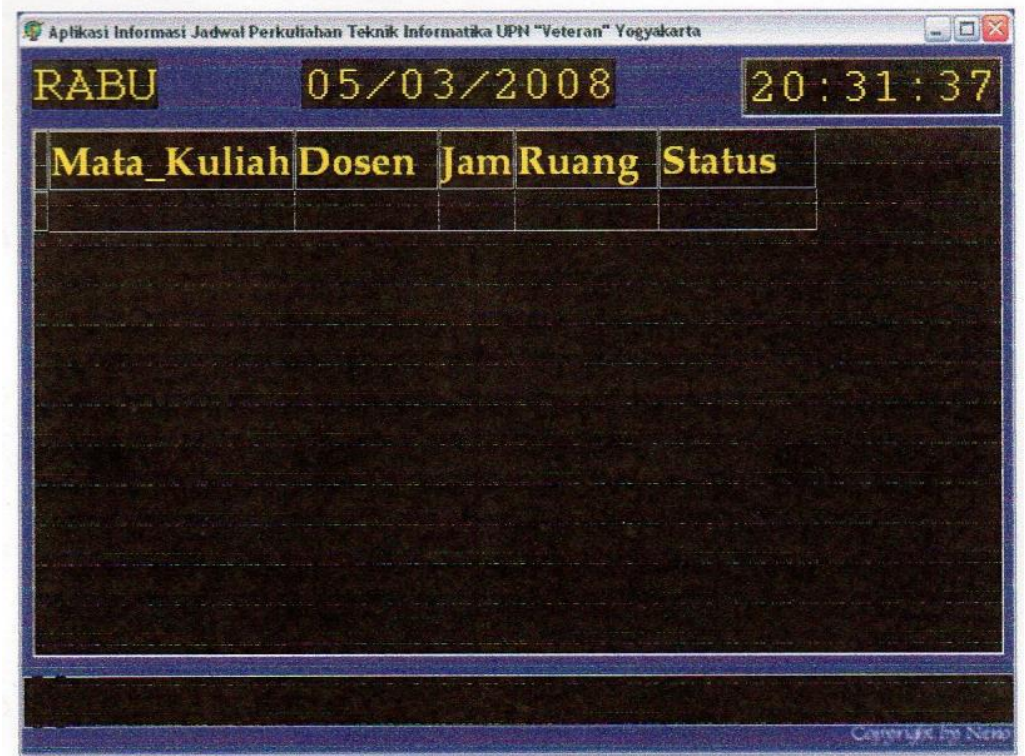

\section{Gambar 13. Halaman Jadwal}

\section{SIMPULAN}

Sistem Informasi Jadwal Perkuliahan Menggunakan Media Televisi (Studi Kasus pada Jurusan Teknik Informatika UPN "Veteran” Yogyakarta) memberikan informasi berupa tulisan yang ditampilkan pada sebuah layar televisi dan suara yang menginformasikan pelaksanaan perkuliahan. Informasi yang diberikan mencakup waktu pelaksanaan perkuliahan, ruangan yang akan digunakan, kepastian pelaksanaan perkuliahan yang akan berlangsung, serta menginformasikan pengumuman-pengumuman dan kegiatan-kegiatan yang akan berlangsung. Sistem ini juga menunjang efektifitas kinerja staff pengajar dalam melakukan kegiatan operasional sehari-hari.

\section{DAFTAR PUSTAKA}

[1]. Barlow, V.M, "System Analysis and Design Method", Penerbit Von Hoffmann Press, USA, 1989.

[2]. Fathansyah, "Buku Teks Ilmu Komputer Basis Data", Penerbit Informatika Bandung, 2001. 
[3]. Hariyanto, B., "Sistem Operasi", Penerbit Informatika Bandung, 1999.

[4]. Jogiyanto, H.M., "Sistem Informasi Berbasis Komputer Edisi 2", BFE Yogyakarta, 1997

[5]. Kadir, A., "Pengenalan Sistem Informasi". Penerbit Andi Yogyakarta, 2002.

[6]. Marcus, T., Prijono, A., Widiadhi, J., "Delphi Developer dan Sql Server 2000", Penerbit Informatika, Bandung, 2004.

[7].Pranata, A., "Pemrograman Borland Delphi 6 Edisi 4", Penerbit Andi, Yogyakarta, 2002.

[8]. Santosa, B., "Modul Praktikum Basis Data", Jurusan teknik Informatika UPN “Veteran”, Yogyakarta, 2004.

[9]. Sundari, R.A., "Aplikasi Informasi Jadwal Perkuliahan Menggunakan Media Televisi (Studi Kasus pada Jurusan teknik Informatika UPN "Veteran" Yogyakarta)", Jurusan teknik Informatika UPN "Veteran", Yogyakarta, 2008. 